\title{
Elastomeric Bearings for Steel Trapezoidal Box Girder Bridges
}

\author{
Timothy E. Bradberry, P.E. ${ }^{1}$, Jeffery C. Cotham, P.E. ${ }^{2}$, and Ronald D. Medlock, P.E. ${ }^{3}$
}

\begin{abstract}
Traditionally, bridge bearings supporting steel trapezoidal box girder (a.k.a. tub girder) superstructures consist of fabricator designed mechanical devices, such as pot or disk bearings (a.k.a. high load, multi-rotational bearings), that may be guided or unguided and are typically expensive to fabricate and place. The performance of these bearings has been mixed, with some being maintenance free and others requiring significant maintenance, repair and/or replacement. In Texas, bridge bearings supporting concrete and steel superstructure types are typically steellaminated elastomeric bearings that are tapered or have a constant thickness. Recently the Texas Department of Transportation has moved toward the use of these structurally engineered elastomeric bearings for steel trapezoidal box girders in place of mechanically engineered pot or disk bearings. This paper presents a discussion of the rationale for the use of elastomeric bearings for steel trapezoidal box girders, a historical overview of bridge bearing systems in Texas, and the design procedure for the elastomeric bearings of the steel trapezoidal box girders of the US 290 \& IH 35 Interchange built in Austin in the late 1990s and place in service in 2001.
\end{abstract}

Keywords: bridge bearings; reinforced elastomeric bearings; laminated elastomeric bearings; steel trapezoidal box girder; tub girder; pot or disk bearing; high load, multi-rotational bearing; rotational capacity; bridge bearing research; design guidelines; low temperature behavior; implementation; bearing suitability; Texas

\section{Introduction}

TxDOT bridge bearing research, design, and installation experience demonstrates that, within certain maximum span lengths and continuous unit lengths, steel trapezoidal box girder (a.k.a. tub girder) bridges can be satisfactorily supported on reinforced elastomeric bearings, rather than more complex high load, multi-rotational bearings. Steel laminated elastomeric bearings can be a simple and economical design solution for trapezoidal box girders. TxDOT prefers elastomeric bearings because they are more forgiving of placement errors and other randomly distributed construction tolerances, they are easily inspected and replaced, and they can be designed to provide easier installation than more sophisticated bearings. TxDOT has developed and implemented design recommendations and procedures for the use of elastomeric bearings on trapezoidal box girder bridges supported by research findings and elastomeric bearing performance in Texas. Presented in the body of this paper are these design recommendations and

\footnotetext{
${ }^{1}$ Support Branch Manager, Bridge Division, Texas Department of Transportation, 125 East $11^{\text {th }}$ Street, Austin, Texas 78701-2483, (512) 416-2179, e-mail: tbradber@dot.state,tx.us.

${ }^{2}$ Fabrication Branch Manager, Bridge Division, Texas Department of Transportation, 125 East $11^{\text {th }}$ Street, Austin, Texas 78701-2483, (512) 416-2179, e-mail: jcotham@ dot.state,tx.us.

${ }^{3}$ Technical Services Section Director, Bridge Division, Texas Department of Transportation, 125 East $11^{\text {th }}$ Street, Austin, Texas 78701-2483, (512) 416-2179, e-mail: rmedloc@ dot.state,tx.us.
} 
procedures, their background and basis, and presented in the Appendix to this paper is a brief history of the use of bridge bearings in Texas.

\section{Overview}

Bearings placed between the bridge girders and their supports have two main functions: support the gravity loads (dead load and live loads) and accommodate the changes in the length of the bridge resulting from temperature variations and rotations caused by bending ${ }^{4}$. Thus, the primary function of a bridge bearing is to transfer forces from the superstructure to the substructure while maintaining stability. To ensure this functionality, all probable forces, environmental effects, and associated movements should be considered, including but not limited to thermal effects, creep and shrinkage effects, wind on superstructure, wind on live load, dead load, live load, and braking forces. The bearings can then be designed to accommodate these phenomena in a stable manner.

Although elastomeric bearings have been developed for precast prestessed concrete girder and steel I-girder bridges in Texas, there are no standard reinforced elastomeric bearings for steel trapezoidal box girders. Bridge engineers must custom design such bearings. Each steel trapezoidal box girder unit should be evaluated for the suitability of reinforced elastomeric bearings, pot bearings, and/or disk bearings, and the suitable bearings designed specifically for the given box girder unit.

According to NCHRP Report 469, "[e]lastomeric bridge bearings, which have been used since 1950, have had remarkably good performance records. A recent survey (Chen and Yura, 1995) of all state DOTs established only a few instances of poor performance. Some pad deterioration, resulting from large shear strains on plain pads, was generally dismissed as poor initial design and not the result of problems with the elastomer material or fabrication of the bearing. There were no reported problems related to fatigue or low temperature behavior. The most common performance problem was slip when the pad was not directly connected to the pier using sole plates or other mechanical devices. Repeated slip that has resulted in the "walking out" of the bearing has been traced to excessive paraffin wax in the rubber that has been added for ozone protection (Muscarella and Yura, 1995; McDonald, 1999)."5 This long term performance record is a significant consideration in the choice of bridge bearing systems for steel tubs.

In the design of these bearings for steel trapezoidal box girders the support forces and movements (translations, rotations, and twists) should be calculated by a rational analysis of the superstructure, including all relevant applied loads and thermal effects, to determine if reinforced elastomeric bearings are suitable. Table 14.5.2.1-"Bearing Suitability" of the AASHTO Standard Specifications for Highway Bridges ${ }^{6}$ (AASHTO Specifications) may prove helpful in determining the suitability of these bearings. In general, reinforced elastomeric bearings are not suitable if the

\footnotetext{
${ }^{4}$ Yura, J., Kumar, A., Yakut, A., Topkaya, C., Becker, E., and Collingwood , J. "Elastomeric Bridge Bearings: Recommended Test Methods", NCHRP Report 449, Transportation Research Board, National Research Couincil, Washington, D.C. (2001), p. 9.

${ }^{5}$ Ibid, p. 3.
}

${ }^{6}$ Standard Specifications for Highway Bridges, $16^{\text {th }}$ Edition, AASHTO, Washington, D.C. (1996) (As Amended by 1997, 1998, 1999, 2000, 2001, and 2002 Interim Specifications-Bridges), p. 347. 
applied loads and allowable pad stresses indicate that very large pads, impractical to fabricate, would be required, or that the pad dimensions limit the rotational capacity below that required. If reinforced elastomeric bearings are not suitable, an alternate system such as pot or disk type bearings is indicated. However, pot or disk type bearings are not suitable for light loads or girder up-lift conditions. Such conditions may be accommodated by elastomeric bearings using the design guidelines and recommendations presented in this paper.

TxDOT has sponsored research ${ }^{7}$ to study elastomeric bearing behavior and design. Research results were published in October 1995. The study findings are important to TxDOT's design method for elastomeric bearings of steel trapezoidal box girders. Of note, researchers found that elastomeric bearings can tolerate far greater rotations than is allowed under the AASHTO Specifications:

"Based on the AASHTO Specifications, bearings of both hardness ratings with 6 shims would be allowed rotations of from 0.004 raidians (0.235 degrees) at $3.85 \mathrm{MPa}$ (550 psi) to 0.010 radians (0.573 degrees) at $7.7 \mathrm{MPa}$ (1100 pis). During rotational stiffness tests in this study [the 9"x14"] bearings were routinely subjected to rotations of 0.033 radians (1.9 degrees). In no case was there any observable sign of damage to the specimen. Liftoff to a $20-30 \mathrm{~mm}(0.79-1.2$ ") depth of separation between the bearing surface and the lever arm was noted at a rotation of 0.0176 radians (1.01 degrees) under $3.85 \mathrm{MPa}$ (550 psi) compressive stress for the 69 durometer bearings and 0.0293 radians (1.68 degrees) for the 54 durometer bearings at $7.7 \mathrm{MPa}$ (1100 psi). In none of the tests was any uplift of the bearing from the bearing seat noted although this is cited as one of the key reasons for the restrictive specifications concerning rotations ${ }^{8,9}$

\section{Design Procedure/Recommendations}

In 1998 TxDOT completed the plans for the US 290 \& IH 35 Interchange in north Austin, which is now in service. The bridge layouts called for each of the four direct connectors to contain one or two twin steel trapezoidal box girder superstructure units. The required curvatures and the underlying roadways and other obstacles, including the main lanes of $\mathrm{IH} 35$, dictated the span arrangements of these trapezoidal box girders. The resulting span and unit lengths presented opportunity to use elastomeric bearings in lieu of the more complex pot and/or disk type bearings normally associated with trapezoidal box girders.

The first draft of these design guidelines and recommendations ${ }^{10}$ was developed after the completion of the plans for the US 290 trapezoidal box girders, in response to a request from the

\footnotetext{
${ }^{7}$ Research Study 3-5-92/4-1304, "Elastomeric Bearings".

${ }^{8}$ Standard Specifications for Highway Bridges, $15^{\text {th }}$ Edition, AASHTO, Washington, D.C. (1992) (As Amended by 1993 and 1994 Interim Specifications-Bridges).

${ }^{9}$ Muscarella, J. V. and Yura, J. A. “An Experimental Study of Elastomeric Bridge Bearings with Design Recommendations", Research Report 1304-3, Center for Transportation Research, Bureau of Engineering Research, The University of Texas at Austin (October 1995), p. 121.

${ }^{10}$ Bradberry, Timothy E. "Design Guidelines for Non-Standard Reinforced Elastomeric Bearings for Steel Trapezoidal Box Girder Bridge Units", draft document, Texas Department of Transportation (1999).
} 
design consultant for the US 71 / Ben White / IH 35 Interchange (now under construction in south Austin). These guidelines and recommendations have been considered but not yet adopted as TxDOT policy or procedures. Thus, these guidelines reflect the views and opinions of the authors and do not necessarily reflect the official view or policy of the Texas Department of Transportation.

The following is list of design guidelines are not presented strictly in order of execution because some iteration of the design process is required:

- The TxDOT Bridge Division procedures for the design of the standard reinforced elastomeric bearings used for conventional type bridges ${ }^{11}$ should be understood before the engineer tries to design non-standard reinforced elastomeric bearings for a steel trapezoidal box girder bridge.

- For load effects, use service loads (i.e. unfactored loads) and concomitant movements. Add 0.005 radians to the calculated trapezoidal box girder transverse and longitudinal twist angles for rotational capacity to accommodate fabrication and placement errors.

- Except as modified for slip as discussed below, use a $50^{\circ} \mathrm{F}$ rise and a $70^{\circ} \mathrm{F}$ fall in temperature (unless a larger range is warranted) to determine overall thermal movements to be accommodated, assuming at installation the mean ambient temperature in the region of the bridge site.

- Assume thermal movements are along a chord from the free bent to the assumed fixed bent (the traditional idea of a fixed bearing is not really achievable with elastomeric bearings). The relative stiffnesses of the bents may be considered when calculating movements only if the stiffnesses of the bearings are appropriately included in the analytical model. Because the actual direction of movement is uncertain, guided bearings are discouraged.

- Use a constant thickness bearing pad resting on a level surface (a variable thickness sole plate is required) to avoid developing gravity load induced horizontal forces in the bearing. In the recent TxDOT research study ${ }^{12}$, researchers found that a flat bearing pad resting on a level surface supporting a sloping superstructure is not subject to significant horizontal forces from gravity loads while a tapered bearing or a bearing have a sloping face is subjected to such forces.

- Rectangular pads are preferred over round pads. The rotational capacity required is dominated by rotation about the transverse axis of bridge. Thus, minimizing the length of the pad parallel to the longitudinal axis of the bridge will provide the most rotational capacity. If required rotational capacity is low (near 0.005 ) round pads may be used, however, round pads are not normally necessary.

\footnotetext{
${ }^{11}$ TxDOT. "Bridge Design Manual", http://manuals.dot.state.tx.us:80/docs/colbridg/forms/des.pdf, Texas Department of Transportation (TxDOT), Austin, Texas, December 2001., pp. 9-83 to 9-86.

${ }^{12}$ Research Study 3-5-92/4-1304, "Elastomeric Bearings".
} 
- Allow a maximum horizontal strain of $50 \%$. Therefore, $\mathrm{T}_{\min }=2 *$ thermal movement in one direction.

- Allow a maximum average total load pad stress of 1500 psi. This is based on findings of the TxDOT research study ${ }^{13}$ which actually indicate that live load pad stresses may be ignored.

- Determine the allowable dead load stress indicated by the calculated shape factor (SF) and assumed shear modulus (using the value at the low end of expected shear modulus range) with no reduction for increased bulging of exterior elastomer layers (i.e. $\beta=1.0$ ). It is valid not to consider bulging of exterior elastomer layers as long as cover layers are no more than 0.375 " thick according to the recommendation of Muscarella, J. V. and Yura, J. A. ${ }^{14}$. Use a target stress of 1000 psi, with a maximum around 1200 psi and a minimum around 550 psi. Use a target SF of approximately 10.0 to 12.0. Increasing the SF means increasing compressive, rotation and shear stiffness. Round the layer thickness to $1 / 8$ " increments within shape factor (SF) constraints.

- Conservatively, attempt to size the bearing pad "conventionally" to prevent slip using a $70^{\circ} \mathrm{F}$ fall in temperature and an assumed "service life maximum temperature range" of $120^{\circ} \mathrm{F}$ (unless a larger range is warranted from the site location). Use the minimum calculated pad load for the bearing pad being designed. Assume $\mu=0.20$ for concrete and steel when the bearing surfaces are non-glossy (wood float finished concrete and mill scaled steel).

- The "conventional" method of designing to preventing pad slip will not be satisfactory for end bearings of most steel trapezoidal box girders. Thus, if the pad will not work when "conventionally" sizing the pad to prevent slip due to the "service life maximum temperature range" (i.e. stability limits on elastomer height are exceeded), an alternate approach may be used with some engineering judgement. Try designing for a "maximum daily temperature range" of $30^{\circ} \mathrm{F}$ (unless a larger range is warranted). This is thought to be the maximum daily temperature fluctuation that the structure can reasonably be expected to experience in Texas. Engineering judgement, backed by research and experience, has been used to support the thesis that "occasional" pad slippage is acceptable, causing no deleterious pad damage (as long as the slip occurs at the pad-beam interface and not along the bearing seat support surface). Use "dead load only" when checking the pad for this "occasional" slip (i.e. don't include any temporal loads which can either reduce or increase the pad stress). Because the "occasional" pad slip accommodates only about $1 / 4$ of the "service life maximum temperature range" it is prudent to attempt to size the pad conventionally first and then reduce the elastomer thickness, until the pad height works, using thickness required to accomodate the "occational" slip "maximum daily temperature range" as the lower limit for calculation of the no-slip pad strain. In support of this approach is the test results from low temperature stiffness tests on elastomeric pads indicating that " $[\mathrm{t}] \mathrm{he}$ value of the maximum shear force depends on

\footnotetext{
${ }^{13}$ Muscarella, J. V. and Yura, J. A. (October 1995), pp. 125-126.

${ }^{14}$ Muscarella, J. V. and Yura, J. A. (October 1995), p. 126.
} 
the daily temperature fluctuations, the type of the elastomeric compound, the average ambient temperature, and the duration of the average ambient temperature"15.

- For 50-durometer grade elastomer, use a more conservative cold temperature shear modulus of 175 psi when checking the pad for slip for the $30^{\circ} \mathrm{F}$ temperature range. When trying to design the pad "conventionally" for slip, use a value of approximately 110-130 psi. This is the mid-to-high end of the $73^{\circ} \mathrm{F}$ shear modulus range for 50 durometer hardness elastomer. TxDOT is presently studying the appropriateness of the $30^{\circ} \mathrm{F}$ "maximum daily temperature range" and working to define "occasional" slippage. Low temperature shear tests on bearing pads indicate that for all but the last bit of movement, the pad shears with an effective modulus around the $73^{\circ} \mathrm{F}$ shear modulus value. Therefore, only the last portion of the temperature range will result in significant stiffening of the pad. Most movement will occur while the pad is "soft" in shear, with only the last bit of movement causing a more rapid increase of the force in the pad which might overcome friction.

- Based on fabricator constructability recommendations, use 11 gage $(0.120$ " thick) steel shims for reinforcement in typical elastomeric bearing applications. For smaller pads (area $<250$ in $^{2}$ and aspect ratio < 1.7), 12 gage $(0.105$ " thick) shims are recommended. For larger pads (area $>850 \mathrm{in}^{2}$ and aspect ratio > 1.7) specify 10 gage $(0.135 "$ thick) shims to help prevent plate bending during fabrication.

- Determine the rotational capacity required by calculating end rotations and twists, but do not use the current AASHTO Specification Article 14.6.5.3.5, "Combined Compression and Rotation" because those provisions are based on the assumption that any amount of bearing pad edge tension will result in pad up-lift (a compromise of bearing stability), contrary to the findings of TxDOT research ${ }^{16}$. (Up-lift is the term used herein for the phenomenon of the pad lifting off of the bearing surface, which can only occur under rotation if the pad is vulcanized to the sole plate. This phenomenon differs from lift-off, which refers to the girder lifting off the edge of the pad under rotation. Up-lift produces tension in the elastomer near the uplifted edge of a vulcanized bearing while lift-off simply decreases the area of the pad available to resist applied compression.) Instead of the current provisions, use the previous AASHTO Specification provision shown ${ }^{17}$ below:

$$
\theta_{\mathrm{TL}, \mathrm{x}}<=2 * \Delta_{\mathrm{C}} / \mathrm{L}
$$

Where:

\footnotetext{
${ }^{15}$ Yura, J., Kumar, A., Yakut, A., Topkaya, C., Becker, E., and Collingwood , J. "Elastomeric Bridge Bearings: Recommended Test Methods" (2001)

${ }^{16}$ Muscarella, J. V. and Yura, J. A. (October 1995), p. 126.

${ }^{17}$ Standard Specifications for Highway Bridges, $15^{\text {th }}$ Edition (1992) (As Amended by 1993 and 1994 Interim Specifications-Bridges), Point Page 298.2.
} 
$\theta_{\mathrm{TL}, \mathrm{x}}=$ Relative rotation (in radians) of the top and bottom bearing surfaces about the transverse axis of the bridge. This is also the rotational capacity of the bearing.

$\Delta_{\mathrm{c}}=$ the instantaneous compressive deflection at the centerline of the bearing.

$\mathrm{L}=$ gross length of the bearing parallel to the longitudinal axis of the girder or the length of bearing along the longitudinal girder axis still engaged after liftoff. If full engagement of the bearing length does not provide enough rotational capacity, up to $20 \%$ lift-off may be assumed as long as the calculated average dead load (DL) and total load (TL) compressive stresses on the reduced pad area do not exceed the allowable stresses.

- To ensure stability, use a minimum total reinforced elastomeric bearing thickness of the smaller of $\mathrm{L} / 3, \mathrm{~W} / 3$, or $\mathrm{D} / 4$

- Provide 1" minimum thickness sole plates to account for girder grade and cross-slope while maintaining a level surface to bear against the top of the pads. Do not use vulcanized sole plates because they may induce tension in the edge of the pad under rotation and they are stiffer in shear, which will result in decreases the pad strain at first slip. The use of sole plates not bonded to elastomeric pads facilitates allowable lift-off under rotation and occasional slip. Slippage between the pad and the sole plate is preferred over slippage between the pad and the concrete bearing surface. Design the sole plate plan dimensions to accommodate any probable slippage while maintaining complete pad coverage.

- If the DL stress is less than 500 psi and the bearing pad is designed "non-conventionally" for slip, recess the pad 1/4" into the bearing seat to prevent it from "walking out" should slip not be confined to the pad-sole plate interface. If non-rotational load induced girder up-lift or close to up-lift conditions are possible, recess the pads into the bearing seats and provide uplift restraints.

\section{TxDOT Implementation of the Elastomeric Bearing Design Procedure}

This design procedure was implemented, as discussed previously, on the US 290 \& IH 35 Interchange in Austin, Texas. The first step was to collect the reactions and rotations that were generated by the designers' structural analyses of the various steel trapezoidal box girder units. A spreadsheet was developed for each trapezoidal box girder unit in which the dead and live load reactions and rotations were stored and the wind, braking force, centrifugal forces, and thermal movements were calculated. The resulting vertical, transverse, and longitudinal forces were summarized in the spreadsheet.

At this point in the design process the decision had not yet been made to go with elastomeric bearings. Preliminary sizing of the bearings showed that elastomeric bearings were feasible and the presence of lightly loaded end bearing locations, including one bearing location subject to girder up-lift, precluded the use of pot or disk bearings. Thus, engineers decided to attempt to use laminated elastomeric bearings at all locations. 
The bearing location forces and rotations for each trapezoidal box girder unit were passed to and tabulated in the elastomeric bearing design spreadsheet. This spreadsheet included all the design calculations required for each bearing, including the following:

- determination of trapezoidal box girder cross-slope and girder slope,

- transverse and longitudinal thermal expansion and contraction, including skew effects,

- maximum and minimum dead and live gravity loads,

- maximum girder rotations,

- minimum and design pad plan dimensions and sole plate plan dimensions,

- minimum sole plate edge distances and corner thicknesses,

- required total elastomer thickness,

- number and size of bearing pad holes required for passing anchor bolts, and the resulting net pad area,

- minimum and maximum average dead and live loads,

- maximum and design inner and outer elastomer layer thicknesses and shape factors,

- minimum shear strain controlled and slip controlled total elastomer thicknesses,

- checks of dead load and total load stresses, including an indication of whether the pad requires recessing in the cap to guard against walk-out,

- a provision for up to $20 \%$ pad lift-off (which was only actually used for one pair of bearings),

- edge stresses due to pad rotation and lift-off,

- minimum and design number of interior elastomer layers,

- total undeformed and deformed pad height,

- multiple AASHTO Specification checks on rotation capacity (AASHTO LRFD and 1996 \& 1987 AASHTO Standard Specifications) — for information only,

- instantaneous and long term strain and rotation capacity analysis, and

- pedestal dimensioning and determination of concrete strength required to resist bearing stresses

Table 1 is a summary of the bearing designs developed by the design procedure and the spreadsheet calculations described above. Figures 1-7 show the elastomeric bearings in place in the US 290 IH 35 Interchange direct connectors.

\section{Conclusions}

TxDOT has found that elastomeric bearings can be used satisfactorily with steel trapezoidal box girders, avoiding the need for more complicated high load multi-rotational bearings. TxDOT has developed and implemented a design procedure for this application of elastomeric bearings. There are departures from the AASHTO Specifications in the design method, but these departures are based on the findings of research sponsored by TxDOT and by NCHRP. TxDOT will pursue implementation of these research finding into the AASHTO Specifications. 
Table 1. Elastomeric Bearing Pad Design Summary - Part I

\begin{tabular}{|c|c|c|c|c|c|c|c|c|c|c|c|c|c|}
\hline & \multicolumn{2}{|c|}{ Sole Plate Bevel } & & & & & & & \\
\hline & & & & & Cross-Slope & Grade & & & & & & & \\
\hline \multirow[t]{2}{*}{$\begin{array}{l}\text { Bent } \\
\text { (Loc) }\end{array}$} & $\begin{array}{l}\text { No. of } \\
\text { Brngs } \\
\text { Req'd } \\
\end{array}$ & $\begin{array}{l}\text { Brng } \\
\text { Type }\end{array}$ & $\begin{array}{l}\text { Brng } \\
\text { Pad } \\
\text { Plan } \\
\text { Dim }\end{array}$ & $\begin{array}{c}\text { Beveled } \\
\text { Slope } \\
\text { Plate }\end{array}$ & $+\mathbf{f t} / \mathbf{f t}$ & $+\mathrm{ft} / \mathrm{ft}$ & $\begin{array}{c}\text { Sole } \\
\text { Plate } \\
\text { Avg } \\
\text { Thk } \\
\end{array}$ & $\begin{array}{c}{ }^{1} \text { No. } \\
\text { of } \\
\text { "t" }\end{array}$ & $\begin{array}{c}{ }^{1} \text { Layer } \\
\text { Thk } \\
\text { "t'" }\end{array}$ & $\begin{array}{c}\text { Unloaded } \\
\text { "T" }\end{array}$ & $\begin{array}{c}2 \text { Loaded } \\
\text { "T" }\end{array}$ & $\begin{array}{c}\text { Total } \\
\text { Unloaded } \\
\text { Bearing } \\
\text { Height }\end{array}$ & $\begin{array}{c}\text { Total } \\
{ }^{2} \text { Loaded } \\
\text { Bearing } \\
\text { Height }\end{array}$ \\
\hline & (ea) & & (in) & (in) & Looking Fwd Sta & Fwd Sta to Right & (in) & (ea) & \begin{tabular}{|l|} 
(in) \\
\end{tabular} & (in) & (in) & (in) & (in) \\
\hline $13 Z(\mathrm{FD})$ & 2 & T-EE1 & $13 \times 20$ & $20 \times 25$ & -0.025 & 0.033 & 2.250 & 7 & 0.500 & 5.207 & 5.070 & 7.457 & 7.320 \\
\hline $14 Z$ & 2 & T-IE1 & $18 \times 36$ & $22 \times 38$ & -0.060 & 0.033 & 2.750 & 4 & 0.500 & 3.348 & 3.258 & 6.098 & 6.008 \\
\hline $15 Z$ & 2 & T-IF1 & $18 \times 36$ & $20 \times 38$ & -0.060 & 0.007 & 2.750 & 4 & 0.500 & 3.348 & 3.242 & 6.098 & 5.992 \\
\hline $16 \mathrm{Z}(\mathrm{BK})$ & 2 & T-EE1 & $13 \times 20$ & $20 \times 25$ & -0.060 & -0.014 & 2.250 & 7 & 0.500 & 5.207 & 5.062 & 7.457 & 7.311 \\
\hline $16 \mathrm{Z}(\mathrm{FD})$ & 2 & T-EE1 & $13 \times 20$ & $20 \times 25$ & -0.060 & -0.015 & 2.250 & 7 & 0.500 & 5.207 & 5.077 & 7.457 & 7.328 \\
\hline $17 Z$ & 2 & T-IF1 & $18 \times 36$ & $20 \times 38$ & -0.060 & -0.034 & 2.750 & 4 & 0.500 & 3.348 & 3.253 & 6.098 & 6.004 \\
\hline $18 \mathrm{Z}(\mathrm{BK})$ & 2 & T-EE1 & $13 \times 20$ & $20 \times 25$ & -0.060 & -0.054 & 2.250 & 7 & 0.500 & 5.207 & 5.078 & 7.457 & 7.328 \\
\hline $17 \mathrm{~K}(\mathrm{FD})$ & 2 & T-EE1 & $13 \times 20$ & $20 \times 25$ & 0.024 & 0.002 & 2.250 & 7 & 0.500 & 5.207 & 5.066 & 7.457 & 7.315 \\
\hline $18 \mathrm{~K}$ & 2 & T-IF2 & $21 \times 36$ & $23 \times 38$ & 0.060 & -0.003 & 2.750 & 4 & 0.500 & 3.348 & 3.237 & 6.098 & 5.987 \\
\hline $19 \mathrm{~K}$ & 2 & T-IE2 & $21 \times 36$ & $25 \times 38$ & 0.060 & -0.011 & 2.750 & 4 & 0.500 & 3.348 & 3.256 & 6.098 & 6.006 \\
\hline $20 \mathrm{~K}(\mathrm{BK})$ & 2 & T-EE1 & $13 \times 20$ & $20 \times 25$ & 0.060 & -0.016 & 2.250 & 7 & 0.500 & 5.207 & 5.066 & 7.457 & 7.316 \\
\hline $1 \mathrm{Y}(\mathrm{FD})$ & 2 & T-EE2 & $14 \times 27$ & $21 \times 31$ & -0.025 & 0.069 & 2.250 & 7 & 0.500 & 5.207 & 5.089 & 7.457 & 7.338 \\
\hline $2 \mathrm{Y}$ & 2 & T-IE2 & $21 \times 36$ & $25 \times 38$ & -0.025 & 0.056 & 2.750 & 4 & 0.500 & 3.348 & 3.254 & 6.098 & 6.004 \\
\hline $3 \mathrm{Y}$ & 2 & T-IF2 & $21 \times 36$ & $23 \times 38$ & -0.060 & 0.029 & 2.750 & 4 & 0.500 & 3.348 & 3.245 & 6.098 & 5.995 \\
\hline $4 Y$ & 2 & T-IE2 & $21 \times 36$ & $25 \times 38$ & -0.060 & 0.003 & 2.750 & 4 & 0.500 & 3.348 & 3.242 & 6.098 & 5.992 \\
\hline $5 \mathrm{Y}(\mathrm{BK})$ & 2 & T-EE2 & $14 \times 27$ & $21 \times 31$ & -0.036 & -0.021 & 2.250 & 7 & 0.500 & 5.207 & 5.028 & 7.457 & 7.278 \\
\hline $10 \mathrm{M}(\mathrm{FD})$ & 2 & T-EE1 & $13 \times 20$ & $20 \times 25$ & 0.056 & 0.039 & 2.250 & 7 & 0.500 & 5.207 & 5.067 & 7.457 & 7.317 \\
\hline $11 \mathrm{M}$ & 2 & T-IE2 & $21 \times 36$ & $25 \times 38$ & 0.056 & 0.039 & 2.750 & 4 & 0.500 & 3.348 & 3.278 & 6.098 & 6.028 \\
\hline $12 \mathrm{M}$ & 2 & T-IF2 & $21 \times 36$ & $23 \times 38$ & 0.056 & 0.022 & 2.750 & 4 & 0.500 & 3.348 & 3.239 & 6.098 & 5.989 \\
\hline $13 \mathrm{M}(\mathrm{BK})$ & 2 & T-EE2 & $14 \times 27$ & $21 \times 31$ & 0.056 & -0.001 & 2.250 & 7 & 0.500 & 5.207 & 5.049 & 7.457 & 7.299 \\
\hline $13 \mathrm{M}(\mathrm{FD})$ & 2 & T-EE1 & $13 \times 20$ & $20 \times 25$ & 0.056 & -0.001 & 2.250 & 7 & 0.500 & 5.207 & 5.113 & 7.457 & 7.364 \\
\hline $14 \mathrm{M}$ & 2 & T-IF3 & $23 \times 36$ & $25 \times 38$ & 0.056 & -0.018 & 2.750 & 5 & 0.500 & 3.968 & 3.837 & 6.718 & 6.587 \\
\hline $15 \mathrm{M}$ & 2 & T-IE3 & $23 \times 36$ & $27 \times 38$ & 0.056 & -0.048 & 2.750 & 5 & 0.500 & 3.968 & 3.856 & 6.718 & 6.605 \\
\hline $16 \mathrm{M}(\mathrm{BK})$ & 2 & T-EE1 & $13 \times 20$ & $20 \times 25$ & 0.016 & -0.069 & 2.250 & 7 & 0.500 & 5.207 & 5.055 & 7.457 & 7.305 \\
\hline
\end{tabular}


Table 2. Elastomeric Bearing Pad Design Summary - Part II

\begin{tabular}{|c|c|c|c|c|c|c|c|c|c|c|c|c|}
\hline $\begin{array}{l}\text { Bent } \\
\text { (Loc) }\end{array}$ & $\begin{array}{c}\text { Max } \\
\text { Allow } \\
\text { Expn } \\
\text { Lgth }\end{array}$ & $\begin{array}{l}\text { Min } \\
\text { Total } \\
\text { Load }\end{array}$ & $\begin{array}{l}\text { Max } \\
\text { Dead } \\
\text { Load }\end{array}$ & $\begin{array}{l}\text { Max } \\
\text { Total } \\
\text { Load }\end{array}$ & $\begin{array}{c}\text { Max } \\
\text { Horz } \\
\text { Force }\end{array}$ & $\begin{array}{c}\text { Req'd } \\
\text { Rotation } \\
\text { Capacity }\end{array}$ & $\begin{array}{c}{ }^{3} \text { Brng } \\
\text { Dist }\end{array}$ & $\begin{array}{c}{ }^{4} \text { Req'd } \\
\text { Min } \\
\text { Bent } \\
\text { Offset }\end{array}$ & $\begin{array}{c}\text { Sole PL } \\
\text { Corner } \\
\text { Thk B1 }\end{array}$ & $\begin{array}{c}\text { Sole PL } \\
\text { Corner } \\
\text { Thk B2 }\end{array}$ & $\begin{array}{c}\text { Sole PL } \\
\text { Corner } \\
\text { Thk B3 }\end{array}$ & $\begin{array}{c}\text { Sole PL } \\
\text { Corner } \\
\text { Thk B4 }\end{array}$ \\
\hline & $(\mathbf{f t})$ & (kips) & (kips) & (kips) & (kips) & (radians) & (in) & (in) & (in) & (in) & (in) & (in) \\
\hline $13 Z(F D)$ & 410 & 83 & 171 & 286 & 19 & 0.019 & 16.00 & NONE & 2.23 & 1.60 & 2.27 & 2.90 \\
\hline $14 Z$ & 265 & 384 & 594 & 784 & 34 & 0.006 & 0.00 & NA & 3.52 & 1.24 & 1.98 & 4.26 \\
\hline $15 Z$ & - & 389 & 590 & 779 & 34 & 0.006 & 0.00 & NA & 3.82 & 1.54 & 1.68 & 3.96 \\
\hline $16 \mathrm{Z}(\mathrm{BK})$ & 357 & 65 & 183 & 309 & 22 & 0.020 & 16.00 & NONE & 3.14 & 1.64 & 1.36 & 2.86 \\
\hline $16 \mathrm{Z}(\mathrm{FD})$ & 333 & 61 & 159 & 288 & 18 & 0.016 & 16.00 & NONE & 3.15 & 1.65 & 1.35 & 2.85 \\
\hline $17 Z$ & - & 366 & 513 & 691 & 30 & 0.005 & 0.00 & NA & 4.23 & 1.95 & 1.27 & 3.55 \\
\hline $18 \mathrm{Z}(\mathrm{BK})$ & 332 & 60 & 158 & 286 & 18 & 0.015 & 16.00 & NONE & 3.54 & 2.04 & 0.96 & 2.46 \\
\hline $17 \mathrm{~K}(\mathrm{FD})$ & 410 & 75 & 177 & 317 & 24 & 0.013 & 16.00 & NONE & 1.93 & 2.53 & 2.57 & 1.97 \\
\hline $18 \mathrm{~K}$ & - & 489 & 796 & 1013 & 40 & 0.010 & 0.00 & NA & 1.64 & 3.92 & 3.86 & 1.58 \\
\hline $19 \mathrm{~K}$ & 265 & 489 & 796 & 1013 & 40 & 0.010 & 0.00 & NA & 1.74 & 4.02 & 3.76 & 1.48 \\
\hline $20 \mathrm{~K}(\mathrm{BK})$ & 410 & 75 & 177 & 316 & 24 & 0.013 & 16.00 & NONE & 1.66 & 3.16 & 2.84 & 1.34 \\
\hline $1 \mathrm{Y}(\mathrm{FD})$ & 410 & 154 & 222 & 346 & 31 & 0.019 & 17.00 & NONE & 1.92 & 1.14 & 2.58 & 3.36 \\
\hline $2 \mathrm{Y}$ & 265 & 594 & 816 & 1076 & 47 & 0.008 & 0.00 & NA & 2.53 & 1.58 & 2.97 & 3.92 \\
\hline $3 Y$ & - & 416 & 723 & 967 & 46 & 0.006 & 0.00 & NA & 3.55 & 1.27 & 1.95 & 4.23 \\
\hline $4 Y$ & 265 & 559 & 949 & 1187 & 49 & 0.011 & 0.00 & NA & 3.85 & 1.57 & 1.65 & 3.93 \\
\hline $5 \mathrm{Y}(\mathrm{BK})$ & - & 54 & 373 & 540 & 32 & 0.024 & 14.50 & -0.8705 & 3.03 & 1.91 & 1.47 & 2.59 \\
\hline $10 \mathrm{M}(\mathrm{FD})$ & 409 & 75 & 176 & 300 & 23 & 0.014 & 16.00 & NONE & 1.16 & 2.56 & 3.34 & 1.94 \\
\hline $11 \mathrm{M}$ & 265 & 391 & 545 & 731 & 37 & 0.006 & 0.00 & NA & 1.19 & 3.32 & 4.31 & 2.18 \\
\hline $12 \mathrm{M}$ & - & 546 & 778 & 987 & 42 & 0.011 & 0.00 & NA & 1.43 & 3.56 & 4.07 & 1.94 \\
\hline $13 \mathrm{M}(\mathrm{BK})$ & 376 & 95 & 321 & 473 & 26 & 0.021 & 16.00 & NONE & 1.39 & 3.13 & 3.11 & 1.37 \\
\hline $13 \mathrm{M}(\mathrm{FD})$ & - & -22 & 103 & 219 & 23 & 0.006 & 16.00 & NONE & 1.56 & 2.96 & 2.94 & 1.54 \\
\hline $14 \mathrm{M}$ & - & 544 & 815 & 1033 & 43 & 0.015 & 0.00 & NA & 1.91 & 4.04 & 3.59 & 1.46 \\
\hline $15 \mathrm{M}$ & 313 & 604 & 945 & 1177 & 45 & 0.011 & 0.00 & NA & 2.34 & 4.46 & 3.16 & 1.04 \\
\hline $16 \mathrm{M}(\mathrm{BK})$ & - & 87 & 194 & 329 & 25 & 0.016 & 16.00 & -2.5 & 2.75 & 3.14 & 1.75 & 1.36 \\
\hline
\end{tabular}

${ }^{3}$ Maximum Bearing Distance used is controlled by required distance to $\mathrm{CL}$ of end diaframs for worse case of beam grade.

"Required Min Bent Offset" is that of CL superstructure joint and CL bent needed to provide at least 4" clear between edge of bearing pad and edge of pedestal. A negative value indicates that $C L$ bent is to be located back station of superstructure CL joint. 


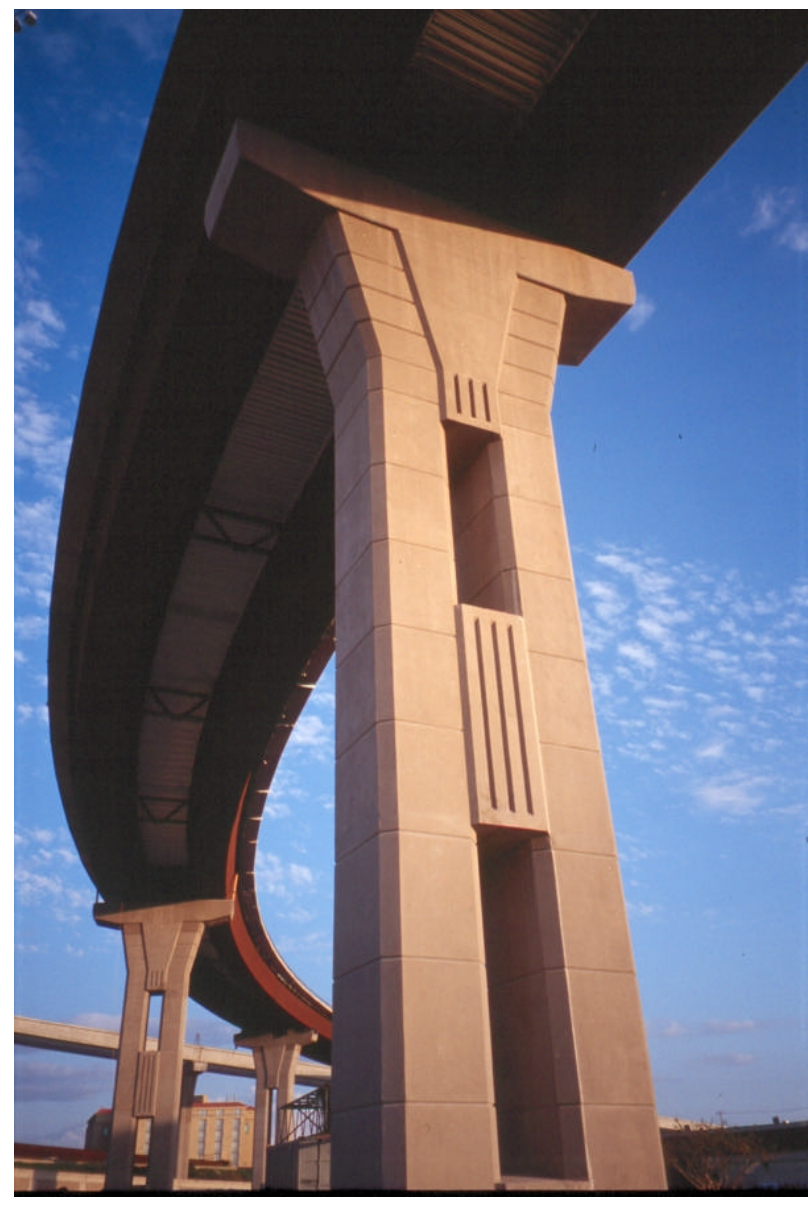

Figure 1. US290 / IH 35 Interchange, Direct Connector " $Z$ ", In Service (August 6, 2002)

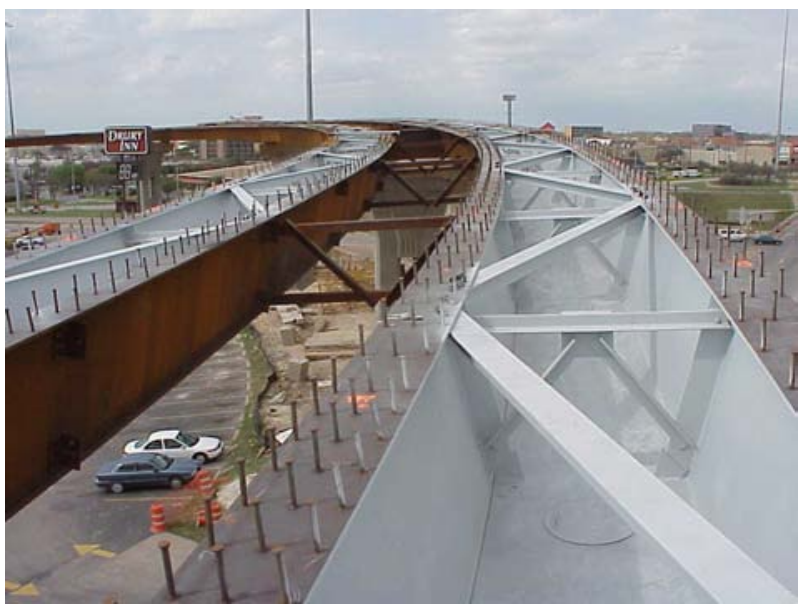

Figure 2. Direct Connector " $Z$ " Erected Steel trapezoidal box girders, During Construction (March 7, 2000)

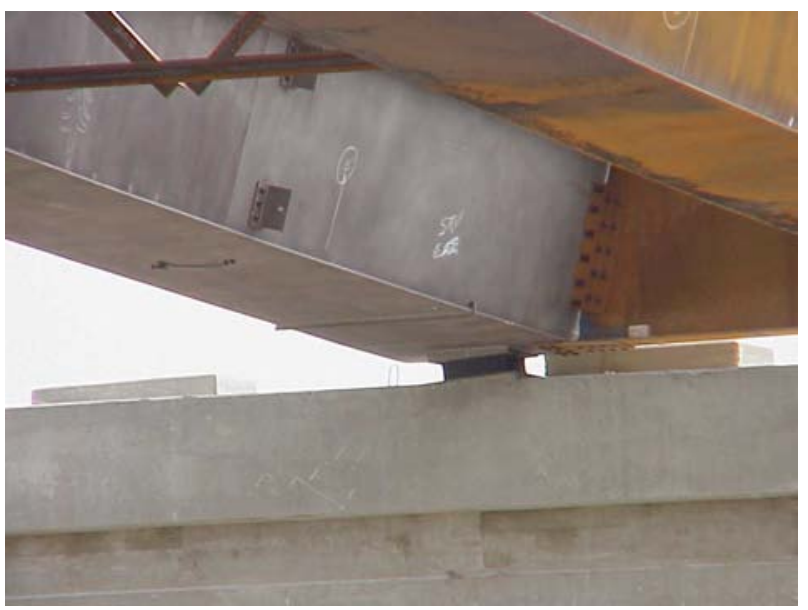

Figure 3. Direct Connector " $Z$ " Steel trapezoidal box girder Unit \#1 End Bearing, During Construction (March 7, 2000) 


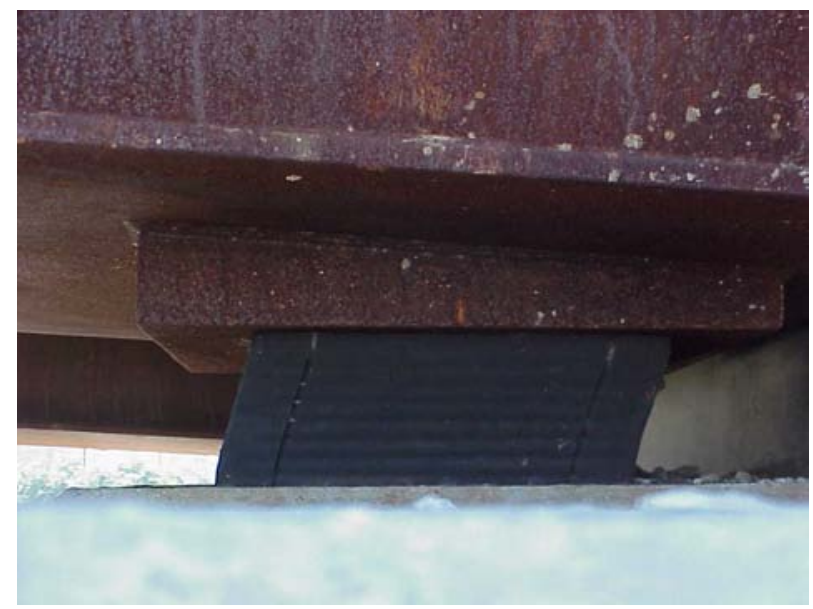

Figure 4. Direct Connector "Y" South Abutment End Bearing Showing Longitudinal Shear Deformation, In Service (August 6, 2002)

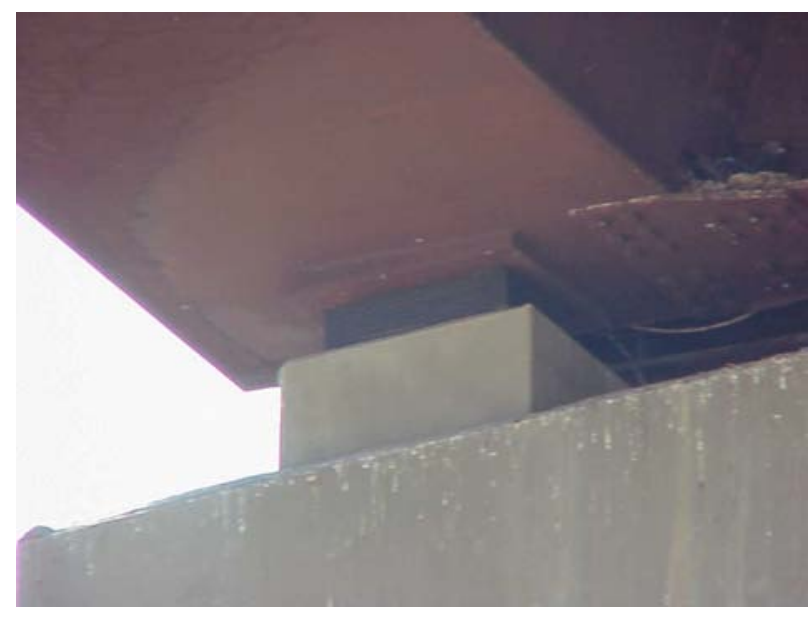

Figure 6. Direct Connector "M" Unit \#1 Interior Bent End Bearing, , In Service (August 6, 2002)

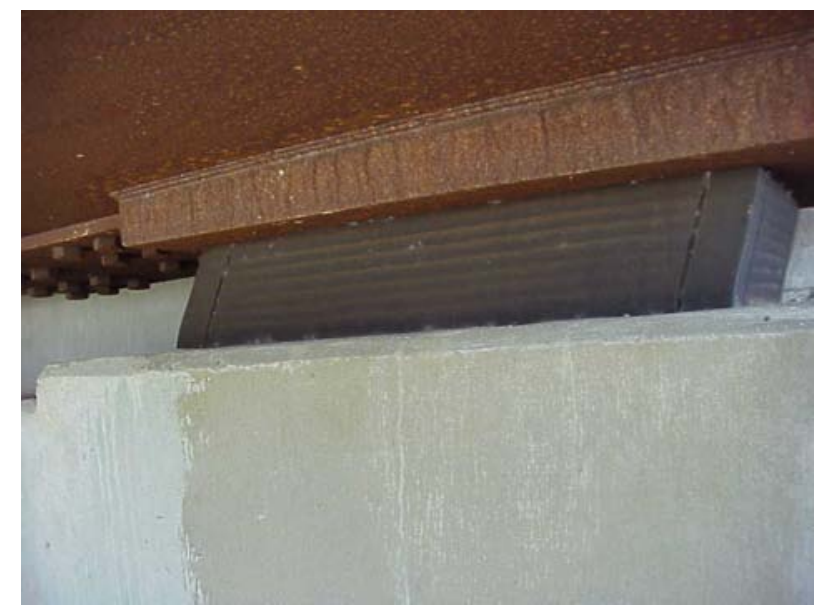

Figure 5. Direct Connector "Y" South Abutment End Bearing Showing Transverse Shear Deformation, In Service (August 6, 2002)

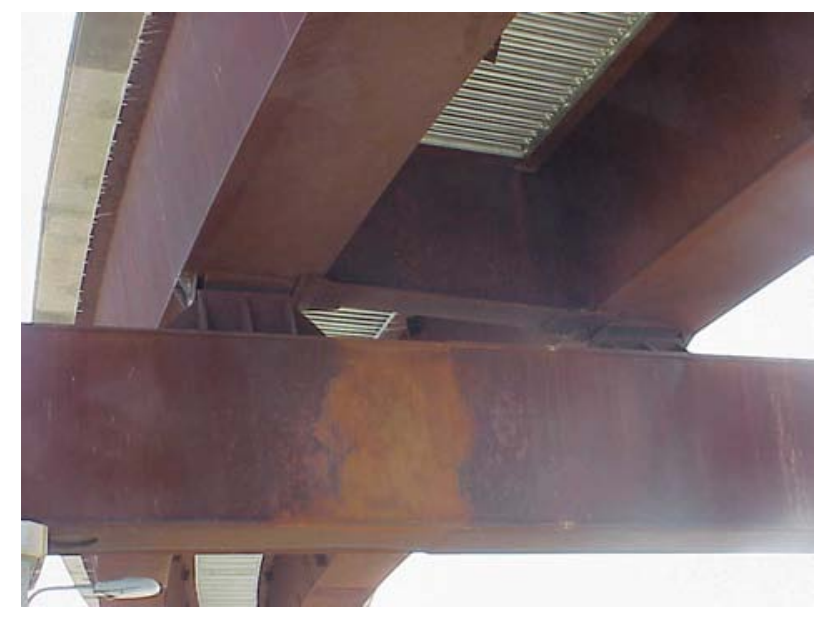

Figure 7. Direct Connector "Y" Unit \#1 Interior Bearing at Steel Box Straddle Bent, In Service (August 6, 2002)

\section{Acknowledgements}

The authors acknowledge the contributions of John Vogel, P.E., of the TxDOT Houston District, Bridge Section, for his technical review of this paper and his spirited questioning which served to improve the discussion. The authors also wish to acknowledge the advice, technical review, and elastomeric bearing research contributions of Dr. Joseph A. Yura, P.E. of the Department of Civil Engineering, The University of Texas at Austin. 


\section{APPENDIX}

\section{Historical Overview of Bridge Bearing Systems for Bridge Superstructures in Texas}

This discussion of the history of bridge bearing use in Texas has been adapted from the discussion in the TxDOT Bridge Design Manual ${ }^{18}$.

Historically, most steel plate girders were designed with bolster shoes like those illustrated in the TxDOT "Bridge Design Manual"19. Since the late 1960s many continuous units have been supported by laminated elastomeric bearings at the interior bents and sliding elastomeric or fabrika bearings at the ends. Refer to the TxDOT standard detail sheet "Elastomeric Bearing Details (For Steel Girders \& Beams)" ${ }^{20}$ for current standard design details. Recently, a few disc and pot bearings have also been used for steel plate girders.

Over 500,000 bearings have been installed for precast prestressed concrete beams in Texas since the late 1950's. With the exception of a few steel bolster shoes, these bearings have consisted of plain and laminated elastomeric pads.

Elastomeric bearings have undergone a controversial and largely empirical design development. In the late 1950's, neoprene bridge bearings had been used in Europe for several years and Dupont began to lobby for their use in the United States. Dupont design data was incorporated into the 1958 AASHTO Specification, under the section on expansion bearings for steel structures ${ }^{21}$. At the time, Texas was already using neoprene bearings under some of the early prestressed concrete beam spans. Ten years later, provisions for elastomeric bearings were placed in a new section of the specification and natural rubber was allowed as an alternative elastomeric material.

It was difficult getting neoprene accepted for bridge bearings initially. Then, controversy over the ability of natural rubber to perform acceptably and continuous arguments over cold temperature requirements delayed the 1968 specifications. Today, serious questions regarding the need for such a conservative design specification continue to confuse the picture.

NCHRP research in 1970 reminded bridge engineers of the variability of elastomeric performance, especially at cold temperatures ${ }^{22}$. More extensive NCHRP research in 1982 led to a specification change in 1985 which the majority of Texas existing bearings could not meet because of shape

\footnotetext{
18 TxDOT, “Bridge Design Manual” (December 2001), pp. 9-72 to 9-78.

${ }^{19}$ TxDOT, "Bridge Design Manual” (December 2001), Figure 9-37, p. 9-74.

${ }^{20}$ TxDOT. "Bridge Division (English) Standards", http://www.dot.state.tx.us/insdtdot/orgchart/cmd/cserve/standard/bridge-e.htm, Standard "Steel Elastomeric Brg", File "sebstde1.pdf" or "sebstde1.dgn" (May 1, 2002 Update).

${ }^{21}$ E.I. Du Pont de Nemours, Inc. "Design of Neoprene Bridge Bearing Pads", Elastomer Chemicals Department, Wilmington, Delaware (1959).

22 NCHRP, "Elastomeric Bearing Research", NCHRP Report 109, Transportation Research Board, National Research Couincil, Washington, D.C. (1970).
} 
factor limitations ${ }^{23}$. Further NCHRP research proposed a more complicated empirical analysis method that allows higher bearing stresses ${ }^{24}$. Round robin load tests performed in early 1980 revealed the ability of steel laminated elastomeric bearings to withstand large compression loads ${ }^{25}$. Further research has been conducted by the Center for Transportation Research (CTR) with a focus on TxDOT practice ${ }^{26}$.

TxDOT elastomeric bearing design practice departs from the AASHTO design specification in several key areas. Taper, allowable compressive stress, cold temperature shear modulus, rotation, and testing procedures for material properties are all areas in which TxDOT has chosen to base its design philosophy on research results as and on extensive field experience.

Heavy concrete box girders, being constructed more frequently in the last few years, place difficult demands on bearings. Usually, two bearings spaced close together on a single-column bent with no cap carry the reactions of a wide roadway. Expansion bearings must allow for horizontal movement of long continuous units and creep of the unit due to prestressing. Texas has used pot bearings, disc bearings, high load sliding elastomeric bearings, and large laminated elastomeric bearings under these conditions.

Most of the steel trapezoidal box girders constructed to date are supported on pot bearings. Design of pot and disc bearings is largely based on manufacturers' recommendations from the results of their own research and testing. For these bearings the condition of the steel backing behind the stainless steel sliding surface is critical because high loads can make the stainless steel assume the shape of the surface beneath.

\footnotetext{
${ }^{23}$ Stanton, J.F. and C.W. Roeder. "Elastomeric Bearings Design, Construction and Materials", NCHRP Report 248, Transportation Research Board, National Research Couincil, Washington, D.C. (1982).

${ }^{24}$ Roeder, C.W. and Stanton, J. F.. "Performance of Elastomeric Bearings," NCHRP Report 298, Transportation Research Board, National Research Couincil, Washington, D.C. (1987).

${ }^{25}$ E.I. Du Pont de Nemours, Inc. "Design of Neoprene Bridge Bearing Pads" (1959).

${ }^{26}$ Research Study 3-5-92/4-1304, "Elastomeric Bearings”.
} 


\section{References}

Bradberry, Timothy E. "Design Guidelines for Non-Standard Reinforced Elastomeric Bearings for Steel Trapezoidal Box Girder Bridge Units”, draft document, Texas Department of Transportation (1999).

E.I. Du Pont de Nemours, Inc. "Design of Neoprene Bridge Bearing Pads", Elastomer Chemicals Department, Wilmington, Delaware (1959).

NCHRP, "Elastomeric Bearing Research", NCHRP Report 109, Transportation Research Board, National Research Couincil, Washington, D.C. (1970).

Muscarella, J. V. and Yura, J. A. “An Experimental Study of Elastomeric Bridge Bearings with Design Recommendations", Research Report 1304-3, Center for Transportation Research, Bureau of Engineering Research, The University of Texas at Austin (October 1995).

Roeder, C.W. and Stanton, J. F.. "Performance of Elastomeric Bearings," NCHRP Report 298, Transportation Research Board, National Research Couincil, Washington, D.C. (1987).

Standard Specifications for Highway Bridges, $15^{\text {th }}$ Edition, AASHTO, Washington, D.C. (1992) (As Amended by 1993 and 1994 Interim Specifications-Bridges).

Standard Specifications for Highway Bridges, $16^{\text {th }}$ Edition, AASHTO, Washington, D.C. (1996) (As Amended by 1997, 1998, 1999, 2000, 2001, and 2002 Interim Specifications-Bridges).

Stanton, J.F. and C.W. Roeder. "Elastomeric Bearings Design, Construction and Materials", NCHRP Report 248, Transportation Research Board, National Research Couincil, Washington, D.C. (1982).

TxDOT. "Bridge Design Manual”, http://manuals.dot.state.tx.us:80/docs/colbridg/forms/des.pdf, Texas Department of Transportation (TxDOT), Austin, Texas, December 2001.

TxDOT. "Bridge Division (English) Standards", http://www.dot.state.tx.us/insdtdot/orgchart/cmd/cserve/standard/bridge-e.htm, Standard "Steel Elastomeric Brg", File "sebstde1.pdf" or "sebstde1.dgn" (May 1, 2002 Update).

Yura, J., Kumar, A., Yakut, A., Topkaya, C., Becker, E., and Collingwood , J. "Elastomeric Bridge Bearings: Recommended Test Methods", NCHRP Report 449, Transportation Research Board, National Research Couincil, Washington, D.C. (2001). 